\title{
A Review of Cancer Immunotherapy Toxicity II: Adoptive Cellular Therapies, Kinase Inhibitors, Monoclonal Antibodies, and Oncolytic Viruses
}

\author{
Neeraj Chhabra ${ }^{1,2}$ (D) Joseph Kennedy ${ }^{1,2}$ \\ Received: 3 December 2020 / Revised: 29 January 2021 / Accepted: 18 February 2021 / Published online: 5 April 2021 \\ (C) American College of Medical Toxicology 2021
}

\begin{abstract}
Immunotherapy for cancer has undergone a rapid expansion in classes, agents, and indications. By utilizing aspects of the body's innate immune system, immunotherapy has improved life expectancy and quality of life for patients with several types of cancer. Adoptive cellular therapies, including chimeric antigen receptor T (CAR T) cell therapy, involve the genetic engineering of patient $\mathrm{T}$ cells to allow for targeting of neoplastic cells. Monitoring of patients during the lymphodepletion prior to therapy and following CAR T cell infusion is necessary to detect toxicity of therapy. Specific toxicities include cytokine release syndrome and neurologic toxicity, both of which may be life-threatening. Tocilizumab and/or corticosteroids should be considered for moderate to severe toxicity. Kinase inhibitor toxicity can occur as "on target" effects or "off target" effects to multiple organ systems due to shared protein epitopes. Treatments are organ-specific. Infusion reactions are common during treatment with monoclonal antibodies and treatment is largely supportive. Clinical experience with oncolytic viruses is limited, but local reactions including cellulitis as well as systemic influenza-like syndromes have been seen but are typically mild. Although clinical experience with adverse effects due to newer immunotherapy agents is growing, an up-to-date understanding of their mechanisms and potential toxicities is critical.
\end{abstract}

Keywords Immunotherapy $\cdot$ Adoptive cellular immunotherapy $\cdot$ Chemotherapy $\cdot$ Oncolytic viruses $\cdot$ Adverse events

\section{Introduction}

The use of immunotherapy is rapidly expanding in the treatment of cancer. Improvements in life expectancy and quality of life for patients with multiple types of cancers have led to an increased utilization of immunotherapy and an expansion in the classes and agents available for use by oncologists [1]. Broadly, immunotherapy harnesses the body's innate immune system to target cancer cells. With the expansion of these agents, clinicians must be aware of the toxicities associated

Supervising Editor: Michael Hodgman, MD

Neeraj Chhabra

NChhabra@cookcountyhhs.org

1 Department of Emergency Medicine, Division of Medical Toxicology, Cook County Health, 1950 W Polk Street, 7th Floor, Chicago, IL 60612, USA

2 Toxikon Consortium, Chicago, IL, USA with their use. The toxicity of immune checkpoint inhibitors was examined in a previous review [2]. The purpose of this second part of our two-part narrative review series is to describe the toxicities and management of other classes of immunotherapy: adoptive cellular therapies, kinase inhibitors, other monoclonal antibodies, and oncolytic viruses.

In this review, we provide a framework for understanding immunotherapy toxicity with recognition of the importance of multidisciplinary care coordination and the implications of administering immunomodulatory therapies. Furthermore, we review evidence to help clinicians understand the varied time course for individual toxicities, ranging from minutes to months following the initiation of therapy.

\section{Methods}

Literature review methodology was described in part one of this narrative review series on cancer immunotherapy toxicity [2]. 


\section{Adoptive Cellular Therapies}

Adoptive cellular therapies (ACTs) are those which harness the architecture of patients' natural T-cells or natural killer cells to detect and eliminate rapidly proliferating neoplasms. The first ACT was developed in 2002 [3]. These therapies represent a major focus of oncologic research over the past few decades [4]. Subsets of ACTs include tumor-infiltrating lymphocyte (TIL) therapy, engineering T cell receptor (TCR) therapy, chimeric antigen receptor $\mathrm{T}$ cell (CAR T) therapy, and natural killer (NK) cell therapy [5]. Of the above therapies, CAR T cell therapy is to date the most promising, and there are currently two FDA-approved engineering processes for the development of chimeric $\mathrm{T}$ cells: tisagenlecleucel (Kymriah $\left.{ }^{\circledR}\right)$ and axicabtagene ciloleucel (Yescarta ${ }^{\circledR}$ ). Although expensive, with tisagenlecleucel priced $\$ 475,000$ in 2017, these drugs have revolutionized oncologic care and require a specialized and multidisciplinary care team [6].

\section{Mechanism of Action}

The process of producing CAR T cells involves collection of patient $\mathrm{T}$ cells followed by genetic engineering to produce a chimeric antigen receptor on the cells' surfaces (Fig. 1). Then, during the next phase occurring over 2 to 3 weeks, cells are replicated until a sufficient number are available for systemic infusion into the patient's bloodstream. The final phase of this process typically occurs during hospital admission, where patients undergo a lymphodepletion chemotherapy regimen to prepare for CAR T cell infusion. The cells are then administered, and patients are monitored for a period ranging from several days to weeks depending on the complications and toxicity that arise. While outpatient therapy has been described and may be associated with increased cost savings, therapy is primarily delivered as an inpatient with some authors advocating for an observation period of at least 9 days $[7,8]$. To date, there are no published cases of significant dosing errors, intentional overdose, or toxicity related to infusion rate errors.

The toxicity associated with ACTs, and CAR T cell therapy in particular, may affect nearly any organ system but ACTs can cause particularly profound neurologic toxicity and systemic toxicity from cytokine release syndrome (CRS). This review is limited to specific toxicities associated with ACTs which occur within eight weeks of $\mathrm{T}$ cell administration. We reference the commonly utilized Common Terminology Criteria for Adverse Events (CTCAE) defined by the US National Cancer Institute [9].

\section{Cytokine Release Syndrome}

Systemic toxicity with CAR T cell therapy consists of both tumor lysis syndrome (TLS) and cytokine release syndrome
(CRS). Diagnosis is complicated by the overlap between these two entities. TLS is characterized by target cell destruction and can be accompanied by electrolyte abnormalities such as hyperuricemia, hyperphosphatemia, and hyperkalemia [10-12]. Although CRS can occur with other immunotherapy agents and disease processes, it is especially common with CAR T cell therapy [13]. Cytokine release syndrome is an acute systemic inflammatory syndrome often characterized by the presence of hyperthermia without an identifiable infectious etiology. CRS typically includes multiple-system organ dysfunction, increased levels of interleukin 6 (IL-6), and capillary leakage. It is caused by a disorganized immunologic response to CAR T cell destruction of hyperproliferative target B cells (or other oncologic targets). Symptoms can develop anywhere from minutes to weeks after the initiation of CAR T cell therapy with the majority of patients experiencing symptoms within 2 weeks $[14,15]$. There is a postulated association between increased cancer burden and the likelihood of developing either TLS or CRS, and the dose of CAR T cells administered may play a role in the development of CRS [16, 17]. A scheme for establishing the diagnosis and a grading system specific for CAR T cell therapy-related CRS has been developed by the American Society for Transplantation and Cellular Therapy (ASTCT) to assist with management and prognosis (Table 1) [13]. Diagnosis may be challenging given the overlap of symptoms of CRS with other disease processes such as infection and sepsis. It is therefore vital for clinicians to elicit a history of recent CAR T cell therapy.

In patients undergoing CAR T cell therapy, CRS develops in $25-75 \%$ of cases [17-19]. The phase II openlabel trial of tisagenlecleucel in pediatric patients with Bcell lymphoblastic leukemia observed an incidence of $60 \%$ of grade 3 or higher CRS. Occasionally, the massive inflammatory response associated with $\mathrm{T}$ cell proliferation is fatal, and was implicated in the deaths of five participants of the ROCKET trial [20]. If there is diagnostic uncertainty, treatment for both sepsis and CRS may be pursued in parallel. In many cases, CRS is reversible with corticosteroid administration, an IL-6 inhibitor such as tocilizumab, or both. Caution must be used in balancing the benefits of preventing further toxicity with risks of subverting the desired clinical effects of CAR T cells, so early consultation with an oncologist is vital $[21,22]$. Some believe that corticosteroids may decrease the efficacy of CAR T cell therapy, although this is controversial. Tocilizumab is considered the first-line agent for the treatment of moderate to severe CRS with corticosteroids reserved for refractory cases after consultation with an oncologist $[15,23]$. IL-6 inhibitors generally have a favorable side effect profile but have been associated with anaphylaxis, cytopenias, derangements in serum aminotransferase levels, and skin and soft tissue infections, all of which may overlap with CRS [24]. 


\section{CAR T-Cell Therapy}

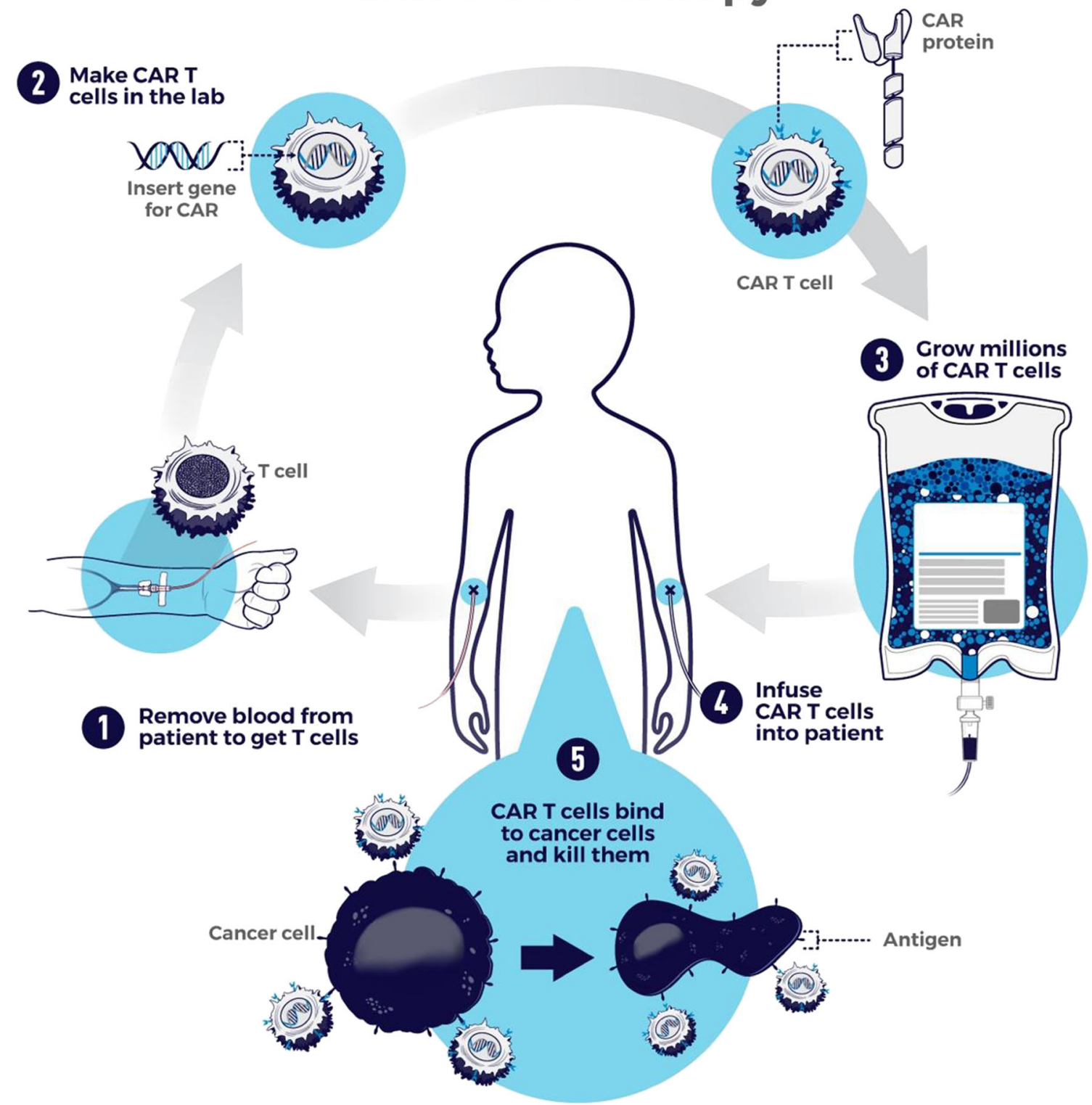

CAR T-cell therapy is a type of treatment in which a patient's T cells are genetically engineered in the laboratory so they will bind to specific protein (antigens) on cancer cells and kill them (1) A patient's T cells are removed from their blood. Then, (2) the gene for a special receptor called a chimeric antigen receptor (CAR) is inserted into the T cells in the laboratory. The gene encodes the engineered CAR protein that is expressed on the surface of the patient's T cells, creating a CAR T cell. (3) Millions of CAR T cells are grown in the laboratory. (4) They are then given to the patient by intravenous infusion. (5) The CAR T cells bind to antigens on the cancer cells and kill them.

\section{cancer.gov}

Fig. 1 CAR T cell therapy procedure (source: National Cancer Institute)

\section{Cardiovascular}

The heart and blood vessels can both experience toxicity with CAR T cell therapy. Vascular toxicity often exists in the context of CRS. CRS may lead to venous capillary leakage and hypotension, but there are no reported cases of medium- or large-vessel vasculitis directly attributable to CAR T cell therapy [10]. The most common cardiovascular toxicity is heart failure, reported in approximately $15 \%$ of patients within 30 days of therapy [25]. Toxicity can occur within minutes to hours or days following therapy, and is correlated with both disease burden and the number of infused T-cells [26]. Direct 
Table 1 Grading system for cytokine release syndrome (CRS) associated with CAR T cell toxicity adapted from Lee et al. [13]

\begin{tabular}{|c|c|c|c|c|}
\hline CRS parameter & $\begin{array}{l}\text { Grade } \\
1\end{array}$ & Grade 2 & Grade 3 & Grade 4 \\
\hline $\begin{array}{l}\text { Temperature } \geq \\
38^{\circ} \mathrm{C}^{*}\end{array}$ & Yes & $\begin{array}{l}\text { Yes } \\
\text { With }\end{array}$ & Yes & Yes \\
\hline $\begin{array}{l}\text { Hypotension (SBP } \\
<90 \mathrm{~mm} \mathrm{Hg} \text { ) }\end{array}$ & None & $\begin{array}{l}\text { None requiring vasopressors } \\
\text { And/ort }\end{array}$ & $\begin{array}{l}\text { Requiring a vasopressor with or } \\
\text { without vasopressin }\end{array}$ & Multiple vasopressors (excluding vasopressin) \\
\hline Hypoxia & None & $\begin{array}{l}\text { Requiring low-flow } \$ \text { nasal } \\
\text { cannula or blow-by oxygen }\end{array}$ & $\begin{array}{l}\text { Requiring HFNC }+ \text {, facemask, } \\
\text { non-rebreather, or Venturi mask }\end{array}$ & $\begin{array}{l}\text { Requiring positive pressure (e.g., CPAP, BiPAP, } \\
\text { intubation and mechanical ventilation) }\end{array}$ \\
\hline
\end{tabular}

SBP, systolic blood pressure; HFNC, high-flow nasal cannula; CPAP, continuous positive airway pressure; BiPAP, bilevel positive airway pressure

*Fever must not be attributable to any other cause, and when antipyretic or anticytokine therapy is initiated (e.g., tocilizumab or steroids), CRS grading is driven by hypotension and hypoxia only

†CRS grading is defined by the more severe event, e.g., a febrile patient on a single vasopressor and low-flow nasal cannula would be classified as Grade 3 CRS

\$Low-flow nasal cannula refers to oxygen delivered at $\leq 6 \mathrm{~L} / \mathrm{min}$, whereas high flow refers to delivery at $>6 \mathrm{~L} / \mathrm{min}$

cardiac toxicity is best understood through the concept of "off target, off organ" toxicity, or the idea that CAR T cells designed to attack a specific antigen on a target cell may affect an organ elsewhere in the body through a shared antigenic epitope. Toxicity not directly attributed to CRS has been observed in cases where CAR T cells were targeted to testis antigen MAGE-A3. A shared peptide structure with the myocardial protein titin may be recognized by $\mathrm{T}$ cells engineered to attack MAGE-A3 and fatal cardiovascular toxicity can follow $[27,28]$.

Fatal direct cardiac toxicity attributable to this shared peptide structure has been reported in multiple patients including one with neutropenic fever 3 days following CAR T cell therapy with progression to shock and hypoxia. An electrocardiogram demonstrated widespread ST-segment elevations and the patient's serum troponin-I measurement was elevated to $54.4 \mathrm{ng} / \mathrm{mL}$. The patient ultimately died of cardiogenic shock and autopsy demonstrated widespread T-cell invasion of the myocardium [27]. Although a thrombus was noted in the left anterior descending artery, there was also extensive myocardial necrosis not explained by the artery's distribution. While percutaneous coronary angiography remains the standard of care for ST-elevation myocardial infarction, toxicologists should be aware of this unique pattern of toxicity. A second patient being treated with CAR $\mathrm{T}$ cell therapy for myeloma refractory to conventional therapy developed a similar presentation and expired from cardiogenic shock complicated by cardiac tamponade. This patient also showed evidence of Tcell invasion and myocardial necrosis but did not have coronary artery occlusion [27]. The treatment of cardiovascular toxicity is directed at the specific etiology and may include corticosteroids or tocilizumab in cases of lymphocytic myocardial infiltration and standard care for heart failure or dysrhythmias [25].

\section{Gastrointestinal and Hepatic}

Similar to the mechanisms responsible for cardiovascular toxicity, gastrointestinal system toxicity may be due to CRS or to a variety of on- and off-target mechanisms. CAR T cell therapy targeting carcinoembryonic antigen (CEA) has been implicated in severe inflammatory colitis occurring 5-8 days following CAR T cell induction [29]. Approximately $15 \%$ of patients undergoing CAR T therapy can be expected to experience gastrointestinal toxicity independent of CRS including emesis, diarrhea, and colitis which can develop within days [30]. The symptoms of direct gastrointestinal toxicity and those associated with CRS are similar. While most gastrointestinal toxicity is mild and self-limiting, severe refractory colitis may require immunomodulator therapy. In these patients, who are immunosuppressed and may have an infectious etiology for colitis, it is essential to conduct a broad workup before initiating locally administered budesonide to the colon. Antibiotic administration, if necessary, should be directed at common gastrointestinal pathogens or by culture, if available. Locally administered steroids are preferred to systemic corticosteroids except in cases of severe toxicity [30]. Reported time to resolution is approximately 4-6 weeks [29].

Hepatotoxicity, as evidenced by elevation of serum aspartate and alanine aminotransferases and bilirubin, is also common, occurring in $7-11 \%$ of patients. It can occur within days or as late as months following CAR T cell infusion. It may be the result of on-target effects among shared peptide epitopes in hepatocytes and canalicular cells [16, 19]. Biliary toxicity has been observed during CAR T cell therapy for renal cell carcinoma secondary to varied expression of surface epithelial carbonic anhydrase IX. Histologic findings on biopsy revealed 
bile duct infiltration, purulent cholangitis, and flow cytometry confirmed the presence of engineered $\mathrm{T}$ cells in the damaged tissue $[31,32]$.

\section{Neurologic}

Immune effector cell-associated neurotoxicity syndrome (ICANS) is the neurologic toxicity associated with CAR T cell therapy. It is common, occurring in up to $40 \%$ of patients [19]. It is often reversible with supportive care, and may present with findings ranging from tremor to necrotizing encephalopathy, coma, and death $[16,21]$. Other presentations include delirium, aphasia, seizures (focal or generalized), cerebral edema, agitation, and word finding difficulties [16, 19, $21,33,34]$. While the median time from infusion to onset of ICANS is approximately 4-5 days[35], signs and symptoms can be immediate or delayed for several weeks [15]. Though most neurologic toxicity involves global symptoms, focal deficits may occur, including mydriasis or motor weakness [36]. The pathophysiology of CAR T cell neurotoxicity has not been fully elucidated, although cerebral edema from CRS is often implicated. Importantly, the ROCKET trial of JCAR015 CAR T cells was halted due to fatalities associated with cerebral edema, and a root-cause analysis suggested that massive cytokine release and changes in vascular permeability contributed to these deaths [20].

The evaluation for CAR T cell therapy-associated neurotoxicity should begin with a thorough examination and urgent computed tomography (CT) to assess for the presence of lifethreatening cerebral edema. Magnetic resonance imaging (MRI) and angiography can help define boundaries of injured tissue, establishing patterns of injury. Along with CT and MRI, lumbar puncture may be indicated to evaluate for alternative causes of symptoms, including intracranial infection, and elevated intracranial pressure suggestive of cerebral edema $[12,34]$. Currently, there is not enough information to recommend the routine use of electroencephalography (EEG), but this diagnostic modality may be useful in certain scenarios (e.g., status epilepticus).

In one series, patients undergoing CAR T cell therapy complicated by status epilepticus requiring mechanical ventilation responded to anticonvulsant agents and survived without neurologic sequelae at 1 year, highlighting the variability in outcomes with neurologic toxicity [34]. Clinicians should also consider the toxicity of other agents in patients with neurologic toxicity. Cyclosporine, for instance, may cause a posteriorreversible encephalopathy syndrome (PRES) [37, 38].

Treatment decisions, including the use of tocilizumab and corticosteroids for neurologic toxicity associated with CAR T cell therapy, is complicated by the lack of a clear pathologic mechanism and risk of negating therapeutic benefit [37]. If evidence of severe cerebral edema is present, hyperosmolar therapy (e.g., mannitol, hypertonic saline) and methylprednisolone $(1000 \mathrm{mg} / \mathrm{day})$ are recommended treatment options. There is some evidence that ICANS is accompanied by a CNS excitatory state and the overproduction of glutamate[39], and benzodiazepine therapy may beneficial in these patients. Given the complexity of each individual case, an oncologist and neurologist should be involved in any instance when tocilizumab or corticosteroids are considered.

\section{Pulmonary}

Hypoxia and respiratory distress often occur in the context of CRS, but rare instances of direct pulmonary toxicity associated with CAR T cell therapy have been described. In one instance, a patient with metastatic colon cancer received a large dose of engineered $\mathrm{T}$ cells $\left(10^{\wedge} 10\right.$ cells $)$ and subsequently developed hypoxia and respiratory distress 15 minutes following the infusion. Massive CRS was identified, and the patient ultimately expired. Autopsy suggested that small amounts of ERBB2 protein on pulmonary epithelial cells recognized by engineered $\mathrm{T}$ cells contributed to the pulmonary injury [14]. Treatment considerations include the correction of hypoxemia with supplemental oxygen and the initiation of positive pressure ventilation when necessary.

\section{Renal}

While acute kidney injury (AKI) may occur with CAR T cell therapy, it is often in the context of TLS, CRS, or renal hypoperfusion due to hypotension and less commonly associated with direct organ-specific toxicity [40]. Electrolyte disorders including hypophosphatemia and hypokalemia were the most commonly noted disturbances in early trials of CAR T cell therapy [41]. In a series of adults undergoing CAR T cell therapy for diffuse large B-cell lymphoma, 19\% experienced acute kidney injury while $8 \%$ progressed to acute tubular necrosis and 6\% required renal replacement therapy (RRT) [42]. These findings were thought to be secondary to either CRS or obstruction without direct nephrotoxicity. Acute tubular necrosis seems to portend a poor prognosis with a 60-day mortality of $67 \%$. In this series, nephrotoxicity was observed to occur at approximately 6-10 days following the administration of CAR T cell therapy. All patients receiving RRT ultimately died within 30 days. It is unknown whether patients who survive after receiving RRT require long-term RRT. Specific risk factors for acute kidney injury include previous stem cell transplantation, ICU admission, and grades 3-4 CRS [43]. There are no specific treatment recommendations for the acute kidney associated with CRS. Supportive care (including renal replacement therapy when necessary) remains the mainstay of treatment. 


\section{Miscellaneous}

Severe CAR T cell toxicity is chiefly limited to the organ systems above except for instances where protein epitopes on sensory organs such as the eyes, ears, and skin are recognized by engineered $\mathrm{T}$ cells targeted to epithelial tissue, specifically during the treatment of melanoma. In one prospective series, 14 of 36 patients being treated for melanoma with MART-1-specific or gp100-specific T cells developed ocular or auditory toxicity including anterior uveitis and hearing loss [44]. Local application of corticosteroids has been beneficial in mitigating ocular and ototoxicity, although persistent vision and hearing impairment was common. In one case, intratympanic corticosteroids were administered with complete resolution of hearing loss. Dermatologic findings are more common and include vitiligo, cutaneous lymphocyte infiltration, superficial infections, and secondary cutaneous malignancies [44, 45]. Vitiligo, cutaneous lymphocyte infiltration, and dermatologic infections occurred early after treatment, typically around 1 week. Secondary cutaneous malignancies and epidermal hyperplasia occurred later, at 5 months or longer following treatment [45].

\section{Kinase Inhibitors}

Kinase inhibitors (KI) are a diverse class of medications which have been used for two decades. The first FDA-approved kinase inhibitor was imatinib mesylate in 2001, which revolutionized the targeted treatment of some types of chronic myelogenous leukemia [46]. The development of new kinase inhibitors includes over 10,000 patents filed since 2001 with 16 new medications granted FDA approval in the last 5 years alone [47]. The recognition of the toxicity of these agents is evolving and remains a moving target. A general scheme for understanding the toxicity of kinase inhibitors is similar to that of CAR T cell therapy, in which effects can either be expected "on target" (e.g., vascular and cardiovascular toxicity with vascular endothelial growth factor (VEGF) inhibitors), or "off-target" and idiosyncratic (as in the case of some BCRAbl inhibitor therapies) [48]. The mainstay of treatment for moderate to severe toxicity from KIs is to withhold the offending drug. The decision to restart KI therapy must be made in conjunction with the patient's oncologist and with an understanding that benefits of anticancer therapy may outweigh the potential toxicity of the agent.

\section{Mechanism of Action}

Protein kinase inhibitors have varied molecular targets but share a common mechanism of action. These agents compete with adenosine triphosphate (ATP) for binding at the catalytic domain of kinase, resulting in inactivation of protein signaling.

\section{Cardiovascular and Pulmonary}

Protein kinase inhibitors including imatinib, dasatinib, nilotinib, sunitinib, sorafenib, and lapatinib are known cardiotoxins [49]. Severe toxicity can result in acute decompensated heart failure or acute coronary syndrome, but more mild toxicity includes subtle electrocardiographic changes and slight elevations in serum troponin measurements [48-50]. Sustained vascular toxicity is described with nilotinib and ponatinib and can be life-threatening. Dasatinib is associated with pulmonary arterial hypertension $(\mathrm{PAH})$ and fluid retention; upwards of $10 \%$ of patients may develop elevations in pulmonary arterial pressures consistent with severe PAH [51]. Severe peripheral arterial disease has been observed in patients treated with both nilotinib and imatinib [52]. Although many KIs carry a risk of QT prolongation, vandetanib, used for the treatment for medullary thyroid cancer, has the highest incidence and carries a black-box warning for QT prolongation and death associated with torsades de pointes [53, 54]. Importantly, the cardiovascular toxicity with KIs may be reversible and, in the case of PAH, discontinuation of the agent is warranted if elevated pulmonary arterial pressures are confirmed [55]. The time to onset of cardiovascular toxicity may be quite prolonged when compared to other immunotherapies. In a large prospective trial evaluating patients treated with sunitinib for gastrointestinal stromal tumor, the median time until a cardiovascular event occurred was 30.5 weeks [56], highlighting the need for regular surveillance. Recognition of significant cardiovascular and pulmonary toxicity should prompt immediate cessation of KI therapy and consultation with an oncologist, cardiologist, and/or pulmonologist to guide therapy.

\section{Dermatologic}

Dermal toxicity is more common with epidermal growth factor receptor (EGFR) inhibitors and can affect patient compliance [57]. Mild rash is common (60-100\%), occurring 1-2 weeks post-initiation of therapy, and includes photosensitivity, fissures, stomatitis, and telangiectasia. Acneiform rash is the most common EGFR inhibitor toxicity, with an incidence of $25-85 \%$ [58]. Treatment is generally supportive and does not preclude continuation of KI therapy. Moderate to severe skin toxicity is less commonly observed, but occurs in 2-18\% of patients treated with erlotinib, gefitinib, and afatinib [59]. Severe toxicity consists of papules or pustules which cover $>30 \%$ of the body's surface area and is associated with limitations of daily life or superinfection of the skin [58]. Treatment is with tetracycline antibiotics, retinoid therapy, and either topical or systemic steroids depending on rash severity. 


\section{Endocrine}

Thyroid toxicity including thyrotoxicosis and hypothyroidism are less common, but have been observed and rarely necessitate cessation of KI therapy [60]. Toxicity occurs, on average, at 1.5 months following the initiation of therapy but can occur as early as within the first week. In some cases, hypothyroidism is permanent [61]. Sunitinib is frequently implicated [62]; however, almost all KIs are associated subclinical thyroid toxicity and patients should have thyroid function evaluated at regular intervals during therapy [60]. Synthetic thyroid hormone (levothyroxine) is the mainstay of treatment and clinicians should monitor indices of thyroid function at regular intervals during treatment.

\section{Gastrointestinal and Hepatic}

Diarrhea is common with KIs. VEGF inhibitor therapy is associated with $>10 \%$ incidence of severe diarrhea $[63,64]$. It may limit patient compliance with KI therapy and result in dehydration and hospitalization [65]. Diarrhea commonly occurs early in the course of treatment but can occur at any time after the initiation of therapy. Although the mechanism of KIassociated diarrhea is incompletely understood, a likely contributing factor is excessive chloride secretion mediated by impaired intracellular signaling [66, 67]. For grades 1-2 acute toxicity, supportive care including loperamide therapy can be considered, while severe cases (grades 3-4) should prompt hospital admission for rehydration and consideration of cessation of KI therapy [68]. There are insufficient data to recommend any prophylactic measures (e.g., diet, probiotic) to prevent toxicity.

Imatinib is associated with acute liver failure leading to death or transplantation, but this severe toxicity remains rare. In most cases, toxicity develops 7 to 20 weeks from initiation of therapy but may occur at any interval $[69,70]$. Risk factors for the development of hepatotoxicity include the presence of viral hepatitis and pretreatment liver impairment. Post-marketing surveillance of imatinib, lapatinib, and sorafenib has led to an increased understanding of KI-associated hepatotoxicity, which is usually reversible with an antibody dose reduction but can rarely progress to cirrhosis or death [71]. For hepatic transaminase elevations greater than 5 times the upper limit of normal, therapy should be interrupted and only resumed at a lower dose when improvement is noted. Patients should be counseled to avoid potential hepatotoxins, such as acetaminophen and alcohol. For more severe progressive or persistent hepatitis, especially with imatinib treatment, therapy may need to be permanently discontinued and treatment with corticosteroids commenced [72, 73].

\section{Neurologic}

KIs are not generally associated with significant neurotoxicity. Unfortunately, owing to their vascular effects, they have been associated with transient ischemic attacks and strokes in 1-3\% of patients [48]. Rapidly progressive intra- and extra-cranial atherosclerosis with nilotinib has been reported but overall remains rare [74]. Time to the onset of atherosclerotic vascular events can be delayed. In one series of patients treated with nilotinib, the median time from treatment initiation to a atherosclerotic vascular event was 42 months [75]. Clinicians should be vigilant for presentations consistent with CNS ischemia in these patients and rapidly mobilize hospital-based stroke teams in a multidisciplinary fashion to determine whether systemic thrombolysis, intraarterial clot retrieval, antiplatelet therapy, or supportive care alone is indicated.

\section{Ophthalmologic}

Owing to the fact that nearly $90 \%$ of the genome is expressed in the tissues of the eye, there are many molecular crossreactive targets for kinase inhibitors [76]. Toxicity can be idiosyncratic and may range from mild conjunctivitis to optic disc edema and optic neuritis which have been noted in patients treated with dasatinib, imatinib, and nilotinib [77]. A rare toxicity of EGFR inhibitor therapy includes trichomegaly, or abnormal growth of the eyelashes, which can lead to backgrowth of the lashes onto the conjunctiva and cornea, leading to corneal ulcerations in severe cases [78]. One of the more concerning toxicities is retinal vein occlusion associated with the mitogen-activated protein kinase (MEK) inhibitors (trametinib, cobimetinib, binimetinib) [79]. Ocular toxicity can occur months following the initiation of KI therapy [78, 80]. Many of the ocular adverse effects associated with KI therapy resolve with discontinuation of the drug; but prompt referral to an ophthalmologist is essential in any suspected case of KI-associated ocular disease.

\section{Other Monoclonal Antibodies}

Monoclonal antibody medications targeted to cancer-specific antigens include agents such as trastuzumab, bevacizumab, and cetuximab. They lack many of the most severe toxicities associated with traditional cytotoxic agents (e.g., myelosuppression), but are associated with infusion reactions, thromboembolism, and cardiotoxicity [81]. Monoclonal antibodies have been associated with all four types of hypersensitivity reaction $[82,83]$. Owing to the broad spectrum of presentation of monoclonal antibody toxicity, we will focus on the most relevant, including infusion reactions and severe cardiovascular and idiosyncratic toxicities. 


\section{Infusion Reactions}

Infusion reactions (IRs) are commonly associated with monoclonal antibody therapy and can present with chills, rigors, and autonomic instability including hypotension and cardiovascular collapse. These can occur during antibody infusion of or within hours of administration [82, 84]. IRs may be difficult to differentiate from anaphylaxis, though the latter tends to occur within minutes (immediate hypersensitivity) while the former tends to present within hours. IRs are most common with rituximab (upwards of $80 \%$ of patients experience an IR at some point during treatment), and are commonly associated with trastuzumab and cetuximab [85]. Unfortunately, 10-30\% of infusion reactions may present after the first infusion [86]. Owing to this fact, monoclonal antibody infusion therapy should occur in a monitored setting with access to resuscitation equipment, even if prior infusions have been uneventful. Cetuximab has a black-box warning indicating a $2-5 \%$ risk of severe infusion reaction with one fatality observed among 1373 patients enrolled in clinical trials. Treatment for infusion reactions is entirely supportive, with caution towards recognizing and differentiating immediate type 1 hypersensitivity reactions and responding appropriately (e.g., antihistamines, epinephrine, corticosteroids, and bronchodilators) [87].

\section{Cardiovascular}

Heart failure associated with trastuzumab toxicity is a potentially life-threatening adverse event that occurs in approximately $1-4 \%$ of patients treated with this agent [88-90]. Trastuzumab is thought to interfere with signaling of human epidermal growth factor receptor 2 (HER2), a member of the EGFR family, in cardiac myocytes and additionally interferes with the repair process of damaged myocytes. Cardiac toxicity may be reversible if trastuzumab is stopped at the onset of toxicity; however, permanent impairment may exist if treatment continues $[91,92]$. Toxicity can occur as early as 2 weeks after initiation of therapy [93]. As trastuzumab had historically been used in conjunction with cardiotoxic anthracycline chemotherapy, risk stratification remains difficult in patients who may receive monotherapy [94]. Monitoring for toxicity with cardiovascular function testing at regular intervals is recommended [95]. Reversible and transient vascular toxicity is associated with bevacizumab and occurs via endothelial dysfunction and smooth muscle cell dysfunction which may result in venous and arterial thrombosis affecting many organ systems [48]. Optimal treatment strategies include beta-blockers, angiotensin-converting enzyme inhibitors (ACE-I), and cessation of the monoclonal antibody [96].
Idiosyncratic and Life-Threatening

Rituximab is rarely associated with life-threatening dermatologic toxicity including Steven's Johnsons syndrome (SJS) and toxic epidermal necrolysis (TEN) [97]. Bevacizumab is associated with poor wound healing, gastrointestinal perforation, and necrotizing fasciitis [98-100]. Furthermore, rare cases of thrombotic microangiopathy have been observed with bevacizumab therapy [101]. Rare but devastating pulmonary toxicity including bronchiolitis obliterans organizing pneumonia (BOOP), diffuse alveolar hemorrhage, and ARDS has been seen with rituximab, more so than with other monoclonal antibodies [82, 102, 103]. Alemtuzumab, a CD52 monoclonal antibody, is unique in that it significantly predisposes patients to T-cell depletion and systemic infections including Pneumocystis jiroveci, CMV, herpes, and EBV [104]. Prophylaxis with antimicrobial agents in patients receiving alemtuzumab (e.g., trimethoprim-sulfamethoxizole, dapsone, and others) may predispose the patient to other adverse drug reactions. For severe and life-threatening toxicities, monoclonal antibody therapy should be discontinued $[105,106]$.

\section{Oncolytic Viruses}

Talimogene laherparepvec (Imlygic $®)$ is a genetically modified type 1 herpes simplex virus which became the first and, thus far, only FDA-approved oncolytic virus (OV) in 2015 for the treatment of advanced stage melanoma [107]. As of 2016, there were 40 clinical trials registered on clinicaltrials.gov recruiting patients with multiple cancer types for treatment with OVs including pancreatic, bladder, and brain malignancies [108]. OVs range in both size and complexity from small single-stranded DNA viruses to large doublestranded DNA viruses. While some wild-type viruses are in clinical use, most have been engineered to improve tumor cell selectivity [108]. OVs have been developed utilizing different virus types including herpesvirus, adenovirus, vaccinia virus, measles virus, and reovirus. OVs differ in their specific cellular entry mechanism, selectivity, and engineering targets. These agents represent a promising and diverse biologic group of genetically engineered viruses for the treatment of cancer.

\section{Mechanism of Action}

Oncolytic viruses treat cancer through a combination of two interconnected mechanisms: selective tumor cell lysis and immune stimulation. OVs are engineered for selective tumor cell lysis through multiple pathways. Cellular entry of OVs occurs via viral entry receptors highly expressed on tumor cells compared to non-tumor cells. Increased viral replication occurs within tumor cells which typically have higher replicative activity compared to non-tumor cells. Selective OV replication within tumor cells is further assisted by tumor cell deficiency 
in antiviral type I interferon signaling [109]. Viral replication within the tumor microenvironment stimulates both innate and adaptive immunity. Cellular lysis leads to the presentation of viral and tumor antigens including damage-associated molecular patterns (DAMPs) and pathogen-associated molecular patterns (PAMPs) [108]. These antigens activate both cytotoxic and helper $\mathrm{T}$ cells in the host [110]. This immune activation may overcome the immunosuppression typically noted in the tumor microenvironment and allow for immunemediated tumor cell targeting. There is some evidence that this immune activation may be further aided by combination therapy with immune checkpoint inhibitors $[110,111]$.

\section{Toxicity}

A wide range of viruses are currently under investigation for the treatment of cancer. Talimogene laherparepvec is most commonly delivered via intra-tumoral injection although OVs delivered by intraperitoneal or intravenous injection are under investigation. Dosing regimens vary widely [108]. Currently published clinical trials have not shown significant safety or toxicity issues. As more OVs undergo clinical testing and an increasing number of patients are studied, safety and toxicity issues are likely to emerge. The possibility of offtarget immune stimulation and cell lysis may result in toxic effects. Additionally, clinical trials have excluded subjects with compromised immune systems and active viral infections. As patients with these conditions may receive OVs in the future, vigilance for toxic effects is critical.

Local reactions at injection sites are common but typically mild. Cellulitis has been described in approximately $1-2 \%$ of patients $[112,113]$. Although injection is directly into the tumor, regression of distal tumors from the injection site has highlighted the potential for systemic effects after local injection. This is likely secondary to systemic immunostimulation. Influenza-like symptoms including fevers and chills have been noted after both local and systemic administration of OVs but are generally mild $[107,111]$. These reactions can be reduced by acetaminophen administration prior to treatment [108]. Cellular carriers of OVs are additional potential causative agents for adverse effects. As reports of severe toxicity are limited, specific treatment recommendations do not yet exist. Of note, OVs engineered from herpes simplex virus 1 (oHSV1) retain their native thymidine kinase gene which facilitates viral replication [108]. This is the target of the antiviral medication ganciclovir, allowing for the possibility of treatment with this agent in the event of severe HSV-based $\mathrm{OV}$ toxicity. To our knowledge, there are currently no reports of $\mathrm{OV}$ overdose in the medical literature.

Person to person transmission of OV has not been described. There are no reports of engineered virus recombination with wild-type virus. In one study, five patients with intralesional OV therapy for melanoma later developed lesions concerning for herpetic infection. Lesions in four of the five patients tested negative for talimogene laherparepvec DNA by quantitative PCR, while the lesion in the other patient tested positive but the area had previously been injected with talimogene laherparepvac [114]. In another study, 3 patients with lesions suspicious for herpetic origin remote from the site of original injection tested positive for talimogene laherparepvec DNA [113]. None of these strains demonstrated infectivity. During treatment, live virus is present in injected lesions and can be detected on the surface of lesions. With appropriate use of occlusive dressings, however, transmission is unlikely as no live virus has been detected on the exterior surface of dressings. Spontaneous reversion of OVs such as oHSV to wild-type HSV is not possible, although the development of compensatory mutations leading to compromised safety is possible but has not yet been described [115].

\section{Conclusions}

The use of immunotherapy for the treatment of cancer has undergone a rapid expansion since 1997. Due to their novel mechanisms of action and increased use, unique immunerelated toxicities are increasingly encountered. These toxicities are often due to off-target immune effects or inflammatory effects, either systemically of within individual organ systems. As clinicians are increasingly likely to encounter patients treated with CAR T cell therapy, monoclonal antibodies, or oncolytic viruses, their unique toxicities must be recognized and managed appropriately. Supportive care, immunosuppression, and multidisciplinary coordination is key to the management of immunotherapy toxicity. While clinical experience with the adverse effects due to these agents is still growing, an understanding of their individual mechanisms and what is known to date is critical for clinicians.

\section{Sources of Funding None}

\section{Declarations}

Conflict of Interest None

\section{References}

1. Yousefi H, Yuan J, Keshavarz-Fathi M, Murphy JF, Rezaei N. Immunotherapy of cancers comes of age. Expert Rev Clin Immunol. 2017;13:1001-15. https://doi.org/10.1080/1744666X. 2017.1366315 .

2. A review of cancer immunotherapy toxicity: Immune checkpoint inhibitors. J Med Toxicol n.d.;submitted for publication.

3. Maher J, Brentjens RJ, Gunset G, Rivière I, Sadelain M. Human T-lymphocyte cytotoxicity and proliferation directed by a single 
chimeric TCR / /CD28 receptor. Nat Biotechnol. 2002;20:70-5. https://doi.org/10.1038/nbt0102-70.

4. Chen DS, Mellman I. Oncology meets immunology: the cancerimmunity cycle. Immunity. 2013;39:1-10. https://doi.org/10. 1016/j.immuni.2013.07.012.

5. Rohaan MW, Wilgenhof S, Haanen JBAG. Adoptive cellular therapies: the current landscape. Virchows Arch Int J Pathol. 2019;474:449-61. https://doi.org/10.1007/s00428-018-2484-0.

6. Bach PB, Giralt SA, Saltz LB. FDA Approval of Tisagenlecleucel: Promise and Complexities of a $\$ 475000$ Cancer Drug. JAMA. 2017;318:1861-2. https://doi.org/10. 1001/jama.2017.15218.

7. Brudno JN, Kochenderfer JN. Recent advances in CAR T-cell toxicity: Mechanisms, manifestations and management. Blood Rev. 2019;34:45-55. https://doi.org/10.1016/j.blre.2018.11.002.

8. Lyman GH, Nguyen A, Snyder S, Gitlin M, Chung KC. Economic Evaluation of Chimeric Antigen Receptor T-Cell Therapy by Site of Care Among Patients With Relapsed or Refractory Large B-Cell Lymphoma. JAMA Netw Open. 2020;3:e202072. https://doi.org/10.1001/jamanetworkopen. 2020.2072 .

9. Common Terminology Criteria for Adverse Events (CTCAE) | Protocol Development | CTEP n.d. https://ctep.cancer.gov/ protocoldevelopment/electronic_applications/ctc.htm\#ctc_50 (accessed January 19, 2021).

10. Porter DL, Hwang W-T, Frey NV, Lacey SF, Shaw PA, Loren $\mathrm{AW}$, et al. Chimeric antigen receptor $\mathrm{T}$ cells persist and induce sustained remissions in relapsed refractory chronic lymphocytic leukemia. Sci Transl Med. 2015;7:303ra139. https://doi.org/10. 1126/scitranslmed.aac5415.

11. Howard SC, Jones DP, Pui C-H. The Tumor Lysis Syndrome. Https://DoiOrg/101056/NEJMra0904569 2011. 10.1056/ NEJMra0904569.

12. $\mathrm{Hu} \mathrm{Y}$, Sun J, Wu Z, Yu J, Cui Q, Pu C, et al. Predominant cerebral cytokine release syndrome in CD19-directed chimeric antigen receptor-modified T cell therapy. J Hematol OncolJ Hematol Oncol. 2016;9:70. https://doi.org/10.1186/s13045-016-0299-5.

13. Lee DW, Santomasso BD, Locke FL, Ghobadi A, Turtle CJ, Brudno JN, et al. ASTCT Consensus Grading for Cytokine Release Syndrome and Neurologic Toxicity Associated with Immune Effector Cells. Biol Blood Marrow Transplant. 2019;25:625-38. https://doi.org/10.1016/j.bbmt.2018.12.758.

14. Morgan RA, Yang JC, Kitano M, Dudley ME, Laurencot CM, Rosenberg SA. Case Report of a Serious Adverse Event Following the Administration of T Cells Transduced With a Chimeric Antigen Receptor Recognizing ERBB2. Mol Ther. 2010;18:843-51. https://doi.org/10.1038/mt.2010.24.

15. Brudno JN, Kochenderfer JN. Toxicities of chimeric antigen receptor T cells: recognition and management. Blood. 2016;127: 3321-30. https://doi.org/10.1182/blood-2016-04-703751.

16. Sun S, Hao H, Yang G, Zhang Y, Fu Y. Immunotherapy with CAR-Modified T Cells: Toxicities and Overcoming Strategies. J Immunol Res. 2018;2018:2386187-10. https://doi.org/10.1155/ 2018/2386187.

17. Annesley CE, Summers C, Ceppi F, Gardner RA. The Evolution and Future of CAR T Cells for B-Cell Acute Lymphoblastic Leukemia. Clin Pharmacol Ther. 2018;103:591-8. https://doi. org/10.1002/cpt.950.

18. Wyatt KD, Bram RJ. Immunotherapy in pediatric B-cell acute lymphoblastic leukemia. Hum Immunol. 2019;80:400-8. https:// doi.org/10.1016/j.humimm.2019.01.011.

19. Maude SL, Laetsch TW, Buechner J, Rives S, Boyer M, Bittencourt $\mathrm{H}$, et al. Tisagenlecleucel in Children and Young Adults with B-Cell Lymphoblastic Leukemia. N Engl J Med. 2018;378:439-48. https://doi.org/10.1056/NEJMoa1709866.
20. Research AA for C. JCAR015 in ALL: A Root-Cause Investigation. Cancer Discov. 2018;8:4-5. https://doi.org/10. 1158/2159-8290.CD-NB2017-169.

21. Kroschinsky F, Stölzel F, von Bonin S, Beutel G, Kochanek M, Kiehl M, et al. New drugs, new toxicities: severe side effects of modern targeted and immunotherapy of cancer and their management. Crit Care Lond Engl. 2017;21:89. https://doi.org/10.1186/ s13054-017-1678-1.

22. Gangadhar TC, Vonderheide RH. Mitigating the toxic effects of anticancer immunotherapy. Nat Rev Clin Oncol. 2014;11:91-9. https://doi.org/10.1038/nrclinonc.2013.245.

23. Le RQ, Li L, Yuan W, Shord SS, Nie L, Habtemariam BA, et al. FDA Approval Summary: Tocilizumab for Treatment of Chimeric Antigen Receptor T Cell-Induced Severe or Life-Threatening Cytokine Release Syndrome. The Oncologist. 2018;23:943-7. https://doi.org/10.1634/theoncologist.2018-0028.

24. Jones G, Ding C. Tocilizumab: A Review of Its Safety and Efficacy in Rheumatoid Arthritis. Clin Med Insights Arthritis Musculoskelet Disord. 2010;3:81-9. https://doi.org/10.4137/ CMAMD.S4864.

25. Lefebvre B, Kang Y, Smith AM, Frey NV, Carver JR, ScherrerCrosbie M. Cardiovascular Effects of CAR T Cell Therapy: A Retrospective Study. JACC CardioOncology. 2020;2:193-203. https://doi.org/10.1016/j.jaccao.2020.04.012.

26. Ganatra S, Carver JR, Hayek SS, Ky B, Leja MJ, Lenihan DJ, et al. Chimeric Antigen Receptor T-Cell Therapy for Cancer and Heart: JACC Council Perspectives. J Am Coll Cardiol. 2019;74: 3153-63. https://doi.org/10.1016/j.jacc.2019.10.049.

27. Linette GP, Stadtmauer EA, Maus MV, Rapoport AP, Levine BL, Emery L, et al. Cardiovascular toxicity and titin cross-reactivity of affinity-enhanced $\mathrm{T}$ cells in myeloma and melanoma. Blood. 2013;122:863-71. https://doi.org/10.1182/blood-2013-03490565.

28. Cameron BJ, Gerry AB, Dukes J, Harper JV, Kannan V, Bianchi FC, et al. Identification of a Titin-Derived HLA-A1-Presented Peptide as a Cross-Reactive Target for Engineered MAGE A3Directed T Cells. Sci Transl Med. 2013;5:197ra103. https://doi. org/10.1126/scitranslmed.3006034.

29. Parkhurst MR, Yang JC, Langan RC, Dudley ME, Nathan D-AN, Feldman SA, et al. T cells targeting carcinoembryonic antigen can mediate regression of metastatic colorectal cancer but induce severe transient colitis. Mol Ther J Am Soc Gene Ther. 2011;19: 620-6. https://doi.org/10.1038/mt.2010.272.

30. Abu-Sbeih H, Tang T, Ali FS, Luo W, Neelapu SS, Westin JR, et al. Gastrointestinal Adverse Events Observed After Chimeric Antigen Receptor T-Cell Therapy. Am J Clin Oncol. 2019;42: 789-96. https://doi.org/10.1097/COC.0000000000000596.

31. Lamers CHJ, Sleijfer S, Vulto AG, Kruit WHJ, Kliffen M, Debets $\mathrm{R}$, et al. Treatment of metastatic renal cell carcinoma with autologous T-lymphocytes genetically retargeted against carbonic anhydrase IX: first clinical experience. J Clin Oncol Off J Am Soc Clin Oncol. 2006;24:e20-2. https://doi.org/10.1200/JCO. 2006.05.9964.

32. Lamers CH, Sleijfer S, van Steenbergen S, van Elzakker P, van Krimpen B, Groot C, et al. Treatment of metastatic renal cell carcinoma with CAIX CAR-engineered T cells: clinical evaluation and management of on-target toxicity. Mol Ther J Am Soc Gene Ther. 2013;21:904-12. https://doi.org/10.1038/mt.2013.17.

33. Maude SL, Frey N, Shaw PA, Aplenc R, Barrett DM, Bunin NJ, et al. Chimeric Antigen Receptor T Cells for Sustained Remissions in Leukemia. N Engl J Med. 2014;371:1507-17. https://doi.org/10.1056/NEJMoa1407222.

34. Morgan RA, Chinnasamy N, Abate-Daga DD, Gros A, Robbins $\mathrm{PF}$, Zheng $\mathrm{Z}$, et al. Cancer regression and neurologic toxicity following anti-MAGE-A3 TCR gene therapy. J Immunother 
Hagerstown Md. 1997;2013(36):133-51. https://doi.org/10.1097/ CJI.0b013e3182829903.

35. Rice J, Nagle S, Randall J, Hinson HE. Chimeric Antigen Receptor T Cell-Related Neurotoxicity: Mechanisms, Clinical Presentation, and Approach to Treatment. Curr Treat Options Neurol. 2019;21:40. https://doi.org/10.1007/s11940-019-0580-3.

36. Mei H, Jiang H, Wu Y, Guo T, Xia L, Jin R, et al. Neurological toxicities and coagulation disorders in the cytokine release syndrome during CAR-T therapy. Br J Haematol. 2018;181:689-92. https://doi.org/10.1111/bjh.14680.

37. Magge RS, DeAngelis LM. The double-edged sword: Neurotoxicity of chemotherapy. Blood Rev. 2015;29:93-100. https://doi.org/10.1016/j.blre.2014.09.012.

38. Dzudie A, Boissonnat P, Roussoulieres A, Cakmak MK, Bejui FT, et al. Cyclosporine-Related Posterior Reversible Encephalopathy Syndrome After Heart Transplantation: Should We Withdraw or Reduce Cyclosporine?: Case Reports. Transplant Proc. 2009;41:716-20. https://doi.org/10.1016/j. transproceed.2009.01.041.

39. Santomasso BD, Park JH, Salloum D, Riviere I, Flynn J, Mead E, et al. Clinical and Biological Correlates of Neurotoxicity Associated with CAR T-cell Therapy in Patients with B-cell Acute Lymphoblastic Leukemia. Cancer Discov. 2018;8:95871. https://doi.org/10.1158/2159-8290.CD-17-1319.

40. Jhaveri KD, Rosner MH. Chimeric Antigen Receptor T Cell Therapy and the Kidney: What the Nephrologist Needs to Know. Clin J Am Soc Nephrol CJASN. 2018;13:796-8. https:// doi.org/10.2215/CJN.12871117.

41. Neelapu SS, Tummala S, Kebriaei P, Wierda W, Gutierrez C, Locke FL, et al. Chimeric antigen receptor T-cell therapy - assessment and management of toxicities. Nat Rev Clin Oncol. 2018;15: 47-62. https://doi.org/10.1038/nrclinonc.2017.148.

42. Gupta S, Seethapathy H, Strohbehn IA, Frigault MJ, O'Donnell EK, Jacobson CA, et al. Acute Kidney Injury and Electrolyte Abnormalities After Chimeric Antigen Receptor T-Cell (CART) Therapy for Diffuse Large B-Cell Lymphoma. Am J Kidney Dis. 2020;76:63-71. https://doi.org/10.1053/j.ajkd.2019.10.011.

43. Gutgarts V, Jain T, Zheng J, Maloy MA, Ruiz JD, Pennisi M, et al. Acute Kidney Injury after CAR-T Cell Therapy: Low Incidence and Rapid Recovery. Biol Blood Marrow Transplant. 2020;26: 1071-6. https://doi.org/10.1016/j.bbmt.2020.02.012.

44. Johnson LA, Morgan RA, Dudley ME, Cassard L, Yang JC, Hughes MS, et al. Gene therapy with human and mouse T-cell receptors mediates cancer regression and targets normal tissues expressing cognate antigen. Blood. 2009;114:535-46. https:// doi.org/10.1182/blood-2009-03-211714.

45. Rubin CB, Elenitsas R, Taylor L, Lacey SF, Kulikovskaya I, Gupta M, et al. Evaluating the skin in patients undergoing chimeric antigen receptor modified T-cell therapy. J Am Acad Dermatol. 2016;75:1054-7. https://doi.org/10.1016/j.jaad.2016. 06.062 .

46. Agrawal M, Garg RJ, Cortes J, Quintás-Cardama A. Tyrosine kinase inhibitors: the first decade. Curr Hematol Malig Rep. 2010;5:70-80. https://doi.org/10.1007/s11899-010-0045-y.

47. Bhullar KS, Lagarón NO, McGowan EM, Parmar I, Jha A, Hubbard BP, et al. Kinase-targeted cancer therapies: progress, challenges and future directions. Mol Cancer. 2018;17:48. https://doi.org/10.1186/s12943-018-0804-2.

48. Herrmann J. Tyrosine Kinase Inhibitors and Vascular Toxicity: Impetus for a Classification System? Curr Oncol Rep. 2016;18: 33. https://doi.org/10.1007/s11912-016-0514-0.

49. Orphanos GS, Ioannidis GN, Ardavanis AG. Cardiotoxicity induced by tyrosine kinase inhibitors. Acta Oncol Stockh Swed. 2009;48:964-70. https://doi.org/10.1080/02841860903229124.

50. Manouchehri A, Kanu E, Mauro MJ, Aday AW, Lindner JR, Moslehi J. Tyrosine Kinase Inhibitors in Leukemia and
Cardiovascular Events: From Mechanism to Patient Care. Arterioscler Thromb Vasc Biol. 2020;40:301-8. https://doi.org/ 10.1161/ATVBAHA.119.313353.

51. Montani D, Bergot E, Günther S, Savale L, Bergeron A, Bourdin A, et al. Pulmonary arterial hypertension in patients treated by dasatinib. Circulation. 2012;125:2128-37. https://doi.org/10. 1161/CIRCULATIONAHA.111.079921.

52. Kim TD, Rea D, Schwarz M, Grille P, Nicolini FE, Rosti G, et al. Peripheral artery occlusive disease in chronic phase chronic myeloid leukemia patients treated with nilotinib or imatinib. Leukemia. 2013;27:1316-21. https://doi.org/10.1038/leu.2013. 70.

53. Zang J, Wu S, Tang L, Xu X, Bai J, Ding C, et al. Incidence and Risk of QTc Interval Prolongation among Cancer Patients Treated with Vandetanib: A Systematic Review and Meta-analysis. PLOS ONE. 2012;7:e30353. https://doi.org/10.1371/journal.pone. 0030353.

54. Porta-Sánchez A, Gilbert C, Spears D, Amir E, Chan J, Nanthakumar K, et al. Incidence, Diagnosis, and Management of QT Prolongation Induced by Cancer Therapies: A Systematic Review. J Am Heart Assoc. 2017;6. https://doi.org/10.1161/ JAHA.117.007724.

55. Chaar M, Kamta J, Ait-Oudhia S. Mechanisms, monitoring, and management of tyrosine kinase inhibitors-associated cardiovascular toxicities. OncoTargets Ther. 2018;11:6227-37. https://doi. org/10.2147/OTT.S170138.

56. Chu TF, Rupnick MA, Kerkela R, Dallabrida SM, Zurakowski D, Nguyen L, et al. Cardiotoxicity associated with tyrosine kinase inhibitor sunitinib. Lancet Lond Engl. 2007;370:2011-9. https:// doi.org/10.1016/S0140-6736(07)61865-0.

57. Kozuki T. Skin problems and EGFR-tyrosine kinase inhibitor. Jpn J Clin Oncol. 2016;46:291-8. https://doi.org/10.1093/jjco/ hyv207.

58. Lacouture M, Sibaud V. Toxic Side Effects of Targeted Therapies and Immunotherapies Affecting the Skin, Oral Mucosa, Hair, and Nails. Am J Clin Dermatol. 2018;19:31-9. https://doi.org/10. 1007/s40257-018-0384-3.

59. Katakami N, Morita S, Yoshioka H, Seto T, Urata Y, Satouchi M, et al. Randomized phase III study comparing gefitinib (G) with erlotinib (E) in patients (pts) with previously treated advanced lung adenocarcinoma (LA): WJOG 5108L. J Clin Oncol. 2014;32:8041. https://doi.org/10.1200/jco.2014.32.15_suppl. 8041 .

60. Jannin A, Penel N, Ladsous M, Vantyghem MC, Do CC. Tyrosine kinase inhibitors and immune checkpoint inhibitors-induced thyroid disorders. Crit Rev Oncol Hematol. 2019;141:23-35. https:// doi.org/10.1016/j.critrevonc.2019.05.015.

61. Illouz F, Laboureau-Soares S, Dubois S, Rohmer V, Rodien P. Tyrosine kinase inhibitors and modifications of thyroid function tests: a review. Eur J Endocrinol. 2009;160:331-6. https://doi.org/ 10.1530/EJE-08-0648.

62. Brown RL. Tyrosine kinase inhibitor-induced hypothyroidism: incidence, etiology, and management. Target Oncol. 2011;6: 217-26. https://doi.org/10.1007/s11523-011-0197-2.

63. Stein A, Voigt W, Jordan K. Chemotherapy-induced diarrhea: pathophysiology, frequency and guideline-based management. Ther Adv Med Oncol. 2010;2:51-63. https://doi.org/10.1177/ 1758834009355164

64. Que Y, Liang Y, Zhao J, Ding Y, Peng R, Guan Y, et al Treatment-related adverse effects with pazopanib, sorafenib and sunitinib in patients with advanced soft tissue sarcoma: a pooled analysis. Cancer Manag Res. 2018;10:2141-50. https://doi.org/ 10.2147/CMAR.S164535.

65. Secombe KR, Van Sebille YZA, Mayo BJ, Coller JK, Gibson RJ, Bowen JM. Diarrhea Induced by Small Molecule Tyrosine Kinase Inhibitors Compared With Chemotherapy: Potential Role of the 
Microbiome. Integr Cancer Ther. 2020;19:1534735420928493. https://doi.org/10.1177/1534735420928493.

66. Harandi A, Zaidi AS, Stocker AM, Laber DA. Clinical Efficacy and Toxicity of Anti-EGFR Therapy in Common Cancers. J Oncol. 2009;2009:1-14. https://doi.org/10.1155/2009/567486.

67. Yang JC-H, Reguart N, Barinoff J, Köhler J, Uttenreuther-Fischer $\mathrm{M}$, Stammberger U, et al. Diarrhea associated with afatinib: an oral ErbB family blocker. Expert Rev Anticancer Ther. 2013;13:72936. https://doi.org/10.1586/era.13.31.

68. Califano R, Tariq N, Compton S, Fitzgerald DA, Harwood CA, Lal R, et al. Expert Consensus on the Management of Adverse Events from EGFR Tyrosine Kinase Inhibitors in the UK. Drugs. 2015;75:1335-48. https://doi.org/10.1007/s40265-015-0434-6.

69. Nacif LS, Waisberg DR, Pinheiro RS, Lima FR, Rocha-Santos V, Andraus $\mathrm{W}$, et al. Imatinib-induced fulminant liver failure in chronic myeloid leukemia: role of liver transplant and secondgeneration tyrosine kinase inhibitors: a case report. J Med Case Reports. 2018;12:63. https://doi.org/10.1186/s13256-018-1588-0.

70. Qian J, Zhang X, Zhang B, Yan B, Wang L, Gu P, et al. Tyrosine Kinase Inhibitor-Related Hepatotoxicity in Patients with Advanced Lung Adenocarcinoma: A Real-World Retrospective Study. Cancer Manag Res. 2020;12:3293-9. https://doi.org/10. 2147/CMAR.S237968.

71. Shah RR, Morganroth J, Shah DR. Hepatotoxicity of tyrosine kinase inhibitors: clinical and regulatory perspectives. Drug Saf. 2013;36:491-503. https://doi.org/10.1007/s40264-013-0048-4.

72. Practical management of tyrosine kinase inhibitor-associated side effects in GIST- ClinicalKey n.d. https://www-clinicalkey-com. ezproxy.rush.edu/\#!/content/playContent/1-s2.0 S0305737210000861?scrollTo=\%23bib76 (accessed January 29, 2021).

73. Tonyali O, Coskun U, Yildiz R, Karakan T, Demirci U, Akyurek $\mathrm{N}$, et al. Imatinib mesylate-induced acute liver failure in a patient with gastrointestinal stromal tumors. Med Oncol. 2010;27:768 73. https://doi.org/10.1007/s12032-009-9284-y.

74. Coon EA, Zalewski NL, Hoffman EM, Tefferi A, Flemming KD. Nilotinib treatment-associated cerebrovascular disease and stroke. Am J Hematol. 2013;88:534-5. https://doi.org/10.1002/ajh. 23442.

75. Gugliotta G, Castagnetti F, Breccia M, Levato L, D'Adda M, Stagno F, et al. Long-term outcome of a phase 2 trial with nilotinib $400 \mathrm{mg}$ twice daily in first-line treatment of chronic myeloid leukemia. Haematologica. 2015;100:1146-50. https://doi.org/10. 3324/haematol.2015.129221.

76. Sheffield VC, Stone EM. Genomics and the eye. N Engl J Med. 2011;364:1932-42. https://doi.org/10.1056/NEJMra1012354.

77. Davis ME. Ocular Toxicity of Tyrosine Kinase Inhibitors. Oncol Nurs Forum. 2016;43:235-43. https://doi.org/10.1188/16.ONF. 235-243.

78. Fabbrocini G, Panariello L, Cacciapuoti S, Bianca D, Ayala F. Trichomegaly of the Eyelashes During Therapy With Epidermal Growth Factor Receptor Inhibitors: Report of 3 Cases. Dermatitis. 2012;23:237-8.

79. Méndez-Martínez S, Calvo P, Ruiz-Moreno O, Pardiñas Barón N, Leciñena Bueno J, Gil Ruiz MDR, et al. OCULAR ADVERSE EVENTS ASSOCIATED WITH MEK INHIBITORS. Retina Phila Pa. 2019;39:1435-50. https://doi.org/10.1097/IAE. 0000000000002451 .

80. Sarny S, Neumayer M, Kofler J, El-Shabrawi Y. Ocular toxicity due to Trametinib and Dabrafenib. BMC Ophthalmol. 2017;17: 146. https://doi.org/10.1186/s12886-017-0541-0.

81. Akiyama S. Specific adverse events caused by monoclonal antibodies, focusing on the prophylaxis and management. Nihon Rinsho Jpn J Clin Med. 2012;70:2199-204.
82. Baldo BA. Adverse events to monoclonal antibodies used for cancer therapy. Oncoimmunology. 2013;2:e26333. https://doi. org/10.4161/onci.26333.

83. Baldo BA, Pham NH. Adverse reactions to targeted and nontargeted chemotherapeutic drugs with emphasis on hypersensitivity responses and the invasive metastatic switch. Cancer Metastasis Rev. 2013;32:723-61. https://doi.org/10.1007/ s10555-013-9447-3.

84. Dillman RO. Infusion reactions associated with the therapeutic use of monoclonal antibodies in the treatment of malignancy. Cancer Metastasis Rev. 1999;18:465-71. https://doi.org/10.1023/a: 1006341717398.

85. Chung $\mathrm{CH}$. Managing premedications and the risk for reactions to infusional monoclonal antibody therapy. The Oncologist. 2008;13:725-32. https://doi.org/10.1634/theoncologist.20080012.

86. Lenz H-J. Management and preparedness for infusion and hypersensitivity reactions. The Oncologist. 2007;12:601-9. https://doi. org/10.1634/theoncologist.12-5-601.

87. Castells MC. Anaphylaxis to chemotherapy and monoclonal antibodies. Immunol Allergy Clin North Am. 2015;35:335-48. https://doi.org/10.1016/j.iac.2015.01.011.

88. Sengupta PP, Northfelt DW, Gentile F, Zamorano JL, Khandheria BK. Trastuzumab-induced cardiotoxicity: heart failure at the crossroads. Mayo Clin Proc. 2008;83:197-203. https://doi.org/ 10.4065/83.2.197.

89. Farolfi A, Melegari E, Aquilina M, Scarpi E, Ibrahim T, Maltoni $\mathrm{R}$, et al. Trastuzumab-induced cardiotoxicity in early breast cancer patients: a retrospective study of possible risk and protective factors. Heart Br Card Soc. 2013;99:634-9. https://doi.org/10.1136/ heartjnl-2012-303151.

90. Curigliano G, Mayer EL, Burstein HJ, Winer EP, Goldhirsch A. Cardiac Toxicity From Systemic Cancer Therapy: A Comprehensive Review. Prog Cardiovasc Dis. 2010;53:94-104. https://doi.org/10.1016/j.pcad.2010.05.006.

91. Albini A, Cesana E, Donatelli F, Cammarota R, Bucci EO, Baravelli M, et al. Cardio-oncology in targeting the HER receptor family: the puzzle of different cardiotoxicities of HER 2 inhibitors. Future Cardiol. 2011;7:693-704. https://doi.org/10.2217/fca.11. 54.

92. Cote GM, Sawyer DB, Chabner BA. ERBB2 inhibition and heart failure. N Engl J Med. 2013;368:876. https://doi.org/10.1056/ NEJMc1215887.

93. Mohan N, Jiang J, Dokmanovic M, Wu WJ. Trastuzumabmediated cardiotoxicity: current understanding, challenges, and frontiers. Antib Ther. 2018;1:13-7. https://doi.org/10.1093/abt/ tby003.

94. Menna P, Minotti G, Salvatorelli E. Cardiotoxicity of Targeted Cancer Drugs: Concerns, "The Cart Before the Horse," and Lessons from Trastuzumab. Curr Cardiol Rep. 2019;21:33. https://doi.org/10.1007/s11886-019-1121-0.

95. Barish R, Gates E, Barac A. Trastuzumab-Induced Cardiomyopathy. Cardiol Clin. 2019;37:407-18. https://doi.org/ 10.1016/j.ccl.2019.07.005.

96. Lynce F, Barac A, Geng X, Dang C, Yu AF, Smith KL, et al. Prospective evaluation of the cardiac safety of HER2-targeted therapies in patients with HER2-positive breast cancer and compromised heart function: the SAFE-HEaRt study. Breast Cancer Res Treat. 2019;175:595-603. https://doi.org/10.1007/s10549019-05191-2.

97. Chen C-B, Wu M-Y, Ng CY, Lu C-W, Wu J, Kao P-H, et al. Severe cutaneous adverse reactions induced by targeted anticancer therapies and immunotherapies. Cancer Manag Res. 2018;10: 1259-73. https://doi.org/10.2147/CMAR.S163391.

98. Shord SS, Bressler LR, Tierney LA, Cuellar S, George A. Understanding and managing the possible adverse effects 
associated with bevacizumab. Am J Health-Syst Pharm AJHP Off J Am Soc Health-Syst Pharm. 2009;66:999-1013. https://doi.org/ 10.2146/ajhp080455.

99. Sliesoraitis S, Tawfik B. Bevacizumab-induced bowel perforation. J Am Osteopath Assoc. 2011;111:437-41.

100. Cortes J, Calvo V, Ramírez-Merino N, O'Shaughnessy J, Brufsky A, Robert N, et al. Adverse events risk associated with bevacizumab addition to breast cancer chemotherapy: a meta-analysis. Ann Oncol Off J Eur Soc Med Oncol. 2012;23:1130-7. https://doi.org/10.1093/annonc/mdr432.

101. Eremina V, Jefferson JA, Kowalewska J, Hochster H, Haas M, Weisstuch J, et al. VEGF Inhibition and Renal Thrombotic Microangiopathy. N Engl J Med. 2008;358:1129-36. https://doi. org/10.1056/NEJMoa0707330.

102. Hadjinicolaou AV, Nisar MK, Parfrey H, Chilvers ER, Ostör AJK. Non-infectious pulmonary toxicity of rituximab: a systematic review. Rheumatol Oxf Engl. 2012;51:653-62. https://doi. org/10.1093/rheumatology/ker290.

103. Lioté H, Lioté F, Séroussi B, Mayaud C, Cadranel J. Rituximabinduced lung disease: a systematic literature review. Eur Respir J. 2010;35:681-7. https://doi.org/10.1183/09031936.00080209.

104. Osterborg A, Karlsson C, Lundin J, Kimby E, Mellstedt H. Strategies in the management of alemtuzumab-related side effects. Semin Oncol. 2006;33:S29-35. https://doi.org/10.1053/j. seminoncol.2006.01.027.

105. Fouda GE, Bavbek S. Rituximab Hypersensitivity: From Clinical Presentation to Management. Front Pharmacol. 2020;11. https:// doi.org/10.3389/fphar.2020.572863.

106. Guan M, Zhou Y-P, Sun J-L, Chen S-C. Adverse Events of Monoclonal Antibodies Used for Cancer Therapy. BioMed Res Int. 2015;2015:1-13. https://doi.org/10.1155/2015/428169.

107. Corrigan PA, Beaulieu C, Patel RB, Lowe DK. Talimogene Laherparepvec: An Oncolytic Virus Therapy for Melanoma. Ann Pharmacother. 2017;51:675-81. https://doi.org/10.1177/ 1060028017702654

108. Lawler SE, Speranza M-C, Cho C-F, Chiocca EA. Oncolytic Viruses in Cancer Treatment: A Review. JAMA Oncol. 2017;3: 841-9. https://doi.org/10.1001/jamaoncol.2016.2064.

109. Stojdl DF, Lichty B, Knowles S, Marius R, Atkins H, Sonenberg $\mathrm{N}$, et al. Exploiting tumor-specific defects in the interferon pathway with a previously unknown oncolytic virus. Nat Med. 2000;6:821-5. https://doi.org/10.1038/77558.

110. Mahalingam D, Wilkinson GA, Eng KH, Fields P, Raber P, Moseley JL, et al. Pembrolizumab in Combination with the Oncolytic Virus Pelareorep and Chemotherapy in Patients with Advanced Pancreatic Adenocarcinoma: A Phase Ib Study. Clin Cancer Res Off J Am Assoc Cancer Res. 2020;26:71-81. https:// doi.org/10.1158/1078-0432.CCR-19-2078.

111. Chesney J, Puzanov I, Collichio F, Singh P, Milhem MM, Glaspy J, et al. Randomized, Open-Label Phase II Study Evaluating the Efficacy and Safety of Talimogene Laherparepvec in Combination With Ipilimumab Versus Ipilimumab Alone in Patients With Advanced, Unresectable Melanoma. J Clin Oncol Off J Am Soc Clin Oncol. 2018;36:1658-67. https://doi.org/10.1200/JCO.2017. 73.7379 .

112. Andtbacka RHI, Kaufman HL, Collichio F, Amatruda T, Senzer $\mathrm{N}$, Chesney J, et al. Talimogene Laherparepvec Improves Durable Response Rate in Patients With Advanced Melanoma. J Clin Oncol Off J Am Soc Clin Oncol. 2015;33:2780-8. https://doi. org/10.1200/JCO.2014.58.3377.

113. Andtbacka RHI, Amatruda T, Nemunaitis J, Zager JS, Walker J, Chesney JA, et al. Biodistribution, shedding, and transmissibility of the oncolytic virus talimogene laherparepvec in patients with melanoma. EBioMedicine. 2019;47:89-97. https://doi.org/10. 1016/j.ebiom.2019.07.066.

114. Chesney J, Awasthi S, Curti B, Hutchins L, Linette G, Triozzi P, et al. Phase IIIb safety results from an expanded-access protocol of talimogene laherparepvec for patients with unresected, stage IIIBIVM1c melanoma. Melanoma Res. 2018;28:44-51. https://doi. org/10.1097/CMR.0000000000000399.

115. Buijs PRA, Verhagen JHE, van Eijck CHJ, van den Hoogen BG. Oncolytic viruses: From bench to bedside with a focus on safety. Hum Vaccines Immunother. 2015;11:1573-84. https://doi.org/10. 1080/21645515.2015.1037058

Publisher's Note Springer Nature remains neutral with regard to jurisdictional claims in published maps and institutional affiliations. 